\title{
Analysis of raw material inventory for insecticide packaging bottle with material requirement planning: a case study
}

Arinda Soraya Putri ${ }^{*}$, Bagus Imron Rosydi

Department of Industrial Engineering, Universitas Muhammadiyah Surakarta, Jl. A. Yani Tromol Pos 1, Sukoharjo 57162, Indonesia

\begin{tabular}{l} 
ARTICLE INFORMATION \\
Article history: \\
Received: November 27, 2020 \\
Revised: December 10, 2020 \\
Accepted: December 12, 2020 \\
\hline Keywords: \\
Bottle packaging \\
Inventory \\
Material requirement planning \\
Pesticide \\
Scheduling \\
*Corresponding Author \\
E-mail: arinda.soraya @ums.ac.id
\end{tabular}

A B $\mathbf{S}$ T $\mathbf{R}$ A $\mathbf{C}$ T

PT. Agricon mostly produces $1 \mathrm{~L}$ package (bottle) pesticides named Spontan insecticide. This study was conducted to analyze and determine the stock inventory of $1 \mathrm{~L}$ bottles for determining an effective ordering schedule based on the calculation of safety stock and reorder points to optimize planning and inventory. Material Requirement Planning (MRP) method used to determine the effective scheduling of $1 \mathrm{~L}$ bottle products. Material Requirement Planning is one method used to determine scheduling with advantages such as reducing inventory, reducing set up costs, and reducing idle time. The proposed order scheme for ordering $1 \mathrm{~L}$ insecticide packaging bottle improve the company on reducing the frequency for ordering bottles from 7 times to 5 times and inventory is more stable and close to demand quantity.

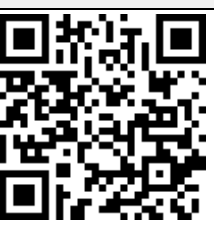

This is an open-access article under the CC-BY-NC-SA license.

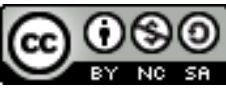

(C) 2020 Some rights reserved

\section{INTRODUCTION}

Raw material planning identically with scheduling, mainly the purpose of scheduling, manages inventory in the best way and within the optimal timeframe [1], [2]. PT. Agricon mainly produces $1 \mathrm{~L}$ pesticide product, which has not implemented safety stock for inventory. When demand decreases, warehouse stock will increase because supplies didn't meet the demand, which is a loss for the company because of inventory cost or tied money. Lack of coordination in the planning division impacts some problems such as too much inventory, bad services, and not optimal capacity utilization [3], [4] Preventing that problem, proper planning, and material control is needed using Material Requirement Planning system [5], [6]. MRP is a manufacturing management system assisting manufacturers in dealing with production planning, scheduling, and inventory control [7], [8]. The advantages of the MRP method are cuts down and optimizes the inventory costs within a production period [9], purchase planning streamlines the production process [10], work scheduling [11], and timesaving [12].

Material Requirement Planning is a method for carrying out production planning to determine the order date and quantity of materials ordered to fill each product component [13], [14]. MRP system also provides appropriate information 
about inventory and production [15], [16]. Material Requirements Planning aims to schedule raw materials, components, and sub-assemblies quantified in the correct quantity and ready at the right time [17], [18]. So MRP needs to keep 1L insecticide packaging bottle inventory meet reorder point and safety stock.

The company produces pesticides, fungicides, insecticides, and herbicides. The demand level is uncertain and not fixed per day, and the company is required to plan the production process sequences precisely to meet consumer needs. The company experienced problems such as high shipping and ordering costs, and raw material inventory was far less than inventory capacity.

The company must maintain raw materials availability such as $1 \mathrm{~L}$ insecticide packaging bottle to expedite the production process. It was scheduling a $1 \mathrm{~L}$ insecticide packaging bottle as its superior product needs to be done to determine the inventory amount in a certain period. The inventory can meet demand, knowing the safe amount of inventory to meet production needs optimally, and minimizing ordering costs by maximizing ordering capacity.

\section{RESEARCH METHODS}

One of the thriving markets that are The first step is Observations and interviews with operators and staff in order to understand the production process at PT. Agricon. Data collection will then continue, such as schedule receipt data, lead time, lot size, demand, truck capacity, and inventory data [19], [20]. Collected data processed using MRP. MRP is a method used for planning and control production and a tool for manage inventory depend on higher item levels [21], [22].

It is possible to get the raw materials needed to complete a product in the future demand using MRP. The company can optimize the required inventory, so it's not too much but not too small either [23]. MRP planning considers time priority to calculate material requirements and schedules supply to meet a product's demand [24].

MRP also considering production planning and computer-based inventory control system related to production scheduling and inventory control [25]. MRP related to production and inventory scheduling to ensure raw material planning must be precise to avoid excess or shortage inventory of raw material [26]. Here Table 1 is the format used in the MRP method.
Table 1. MRP

\begin{tabular}{llllll}
\hline \multicolumn{1}{c}{ Item } & \multicolumn{3}{c}{ Period } \\
\hline \multicolumn{1}{c}{ Lead time } & $\mathbf{1}$ & $\ldots$ & $\ldots$ & $\ldots$ & $\mathbf{t}$ \\
\hline Gross requirement & & & & & \\
Schedule receipt & & & & & \\
Project on hand & & & & \\
Net requirement & & & & \\
Planned order receipt & & & & \\
Planned order release & & & & \\
\hline
\end{tabular}

MRP formulation and calculation [17]:

$$
\begin{aligned}
\text { POH } & =\operatorname{Max}\{0, \text { POH }(t-1)+\text { SRt }- \text { GRt } \\
\text { NRt } & =\operatorname{Max}\{0, \text { GRt }- \text { POH }(t-1)-S R t\} \\
\text { PoRect } & =\text { NRt } \\
\text { PoRelt } & =\text { PoRect }
\end{aligned}
$$

The explanation of the notations in the formula: it is Gross Requirement on t-period, $S R t$ is Schedule Receipt on t-period, POHt is Project On Hand on t-period, NRt is Net Requirement on t-period, PoRect is Planned Order Receipt on tperiod, and PoRelt is Planned Order Release on tperiod.

\section{RESULTS AND DISCUSSION}

PT. Agricon applies total product requirement in a month's production. 1L insecticide packaging bottle demand in July is 72,171 Units. The maximum storage capacity for a $1 \mathrm{~L}$ insecticide packaging bottle is 100,000 Units. The total quantity available for the $1 \mathrm{~L}$ insecticide packaging bottle on $1^{\text {st }}$ July is 71,700 Units. Schedule receipt contains information about the quantity and date of raw material in-house. Table 2 below is the schedule receipt for some package.

Table 2. The arrival date of $1 \mathrm{~L}$ insecticide bottle

\begin{tabular}{crrrrr}
\hline \multicolumn{3}{c}{ Arrival date of 1l insecticide bottle } \\
\hline \multicolumn{2}{c}{$\mathbf{2 0 0}$ ml } & \multicolumn{2}{c}{$\mathbf{5 0 0 ~ m l}$} & \multicolumn{2}{c}{$\mathbf{1 0 0 0}$ L } \\
\hline $\begin{array}{c}\text { Receipt } \\
\text { date }\end{array}$ & Units & $\begin{array}{c}\text { Receipt } \\
\text { date }\end{array}$ & Units & $\begin{array}{c}\text { Receipt } \\
\text { date }\end{array}$ & Units \\
\hline $02 / 07$ & 9078 & $02 / 07$ & 5922 & $04 / 07$ & 14000 \\
$02 / 07$ & 8122 & $10 / 07$ & 21000 & $12 / 07$ & 5040 \\
$22 / 07$ & 11000 & $10 / 07$ & 9144 & $18 / 07$ & 8050 \\
& & $12 / 07$ & 5856 & $19 / 07$ & 15050 \\
& $12 / 07$ & 1144 & $23 / 07$ & 14560 \\
& $12 / 07$ & 3736 & $26 / 07$ & 7070 \\
& & & $30 / 07$ & 110 \\
& & & & $30 / 07$ & 13590 \\
\hline
\end{tabular}


Safety stock calculation for 1L insecticide packaging bottle:

Value Z (95\%) : :1.65

Std deviation overall demand $=34,110$

Lead Time $=11$ days

Safety Stock $=Z *$ Std Deviation $* \sqrt{\text { LeadTime }}$ $=1.65 \times 34,11 \times \sqrt{ } 11$

$$
=18,667 \text { units }
$$

Based on the calculation safety stock for the 1L insecticide packaging bottle is 18,667 Units. Below Table 3 is MRP calculation for $1 \mathrm{~L}$ insecticide packaging bottle based on the gross requirement in July 2019 with total quantity 72,171 Units and opening stock (on Hand) is 71,700 Units.

Example:

Period 11

$$
\begin{aligned}
\text { GRt } & =\text { GR } 12=8008 \\
\text { SRt } & =\text { SR } 12=5040 \\
\text { POH11 } & =69687 \\
\text { POH12 } & =\operatorname{Max}\{0, \operatorname{POH}(t-1)+\text { SRt-GRt }\} \\
& =\operatorname{Max}\{0, \operatorname{POH}(11)+\text { SR } 12-G R 12\} \\
& =\operatorname{Max}\{0,69687+5040-8008\} \\
& =66719
\end{aligned}
$$

$N R t=\operatorname{Max}\{0$, GRt $-P O H(t-1)-S R t\}$

NRI1 = O (becuase POH (t-1) fulfill GRt)

PoRect $=$ PoRect $=0$

PoRelt $=$ PoRelt $=0$

MRP 1L insecticide packaging bottle calculation proposed considering various factors such as total request, store inventory capacity, safety stock, truck capacity, and reorder point. So schedule receipt calculation will be:

Total Gross Req in 1 month $\quad=72.171$ units

Store Capacity $\quad=100.000$ units

Safety Stock $\quad=18.667$ units

Truck Capacity $\quad=15.050$ units

Demand every 11 days in/ Month $=3$

Reorder point period $1(1-11)=34.680$ units

Reorder point period $2(12-23)=66.824$ units

Reorder point period 3 (24-30) = 26.668 units

\begin{tabular}{|c|c|c|c|c|c|c|c|c|c|c|}
\hline \multirow{2}{*}{$\begin{array}{l}\text { Item: } 1 \mathrm{~L} \text { bottle } \\
\text { Lead Time : } 11\end{array}$} & \multirow[b]{2}{*}{1} & \multicolumn{9}{|c|}{ Period } \\
\hline & & 2 & 3 & 4 & . & . & 27 & 28 & 29 & 30 \\
\hline \multicolumn{11}{|l|}{ Gross requirement } \\
\hline Schedule receipt & & & & 14000 & & & & & & 13700 \\
\hline Project on hand & 71700 & 71700 & 71700 & 85700 & . & . & 63299 & 63299 & 63299 & 76999 \\
\hline Net requirement & 0 & 0 & 0 & 0 & . & . & 0 & 0 & 0 & 0 \\
\hline \multicolumn{11}{|l|}{ Planned order receipt } \\
\hline Planned order release & & & & & & & & & & \\
\hline
\end{tabular}

Example reorder point period 1 calculation

Reorder Point $=$ Safety stock + demand in $\mathrm{t}$

\begin{tabular}{|c|c|c|c|c|c|c|c|c|c|c|}
\hline Item: 1L bottle & & & & & & & riod & & & \\
\hline Lead time : 11 & 1 & 2 & 3 & 4 & . & . . & 27 & 28 & 29 & 30 \\
\hline $\begin{array}{l}\text { Gross requirement } \\
\text { Schedule receipt }\end{array}$ & & & & & & & & & & \\
\hline Project on hand & 71700 & 71700 & 71700 & 71700 & . & & 74779 & 74779 & 74779 & 74779 \\
\hline $\begin{array}{l}\text { Net requirement } \\
\text { Planned order receipt } \\
\text { Planned order release }\end{array}$ & 0 & 0 & 0 & 0 & . & & 0 & 0 & 0 & 0 \\
\hline
\end{tabular}

Reorder Point $=18667+8008+8005=34680$ units

The following Table 4 is the proposed MRP calculations on 1L insecticide packaging bottle.

Table 3. Calculation MRP 1L insecticide packaging bottle - the initial condition

Table 4. Calculation MRP 1L insecticide packaging bottle - proposed 


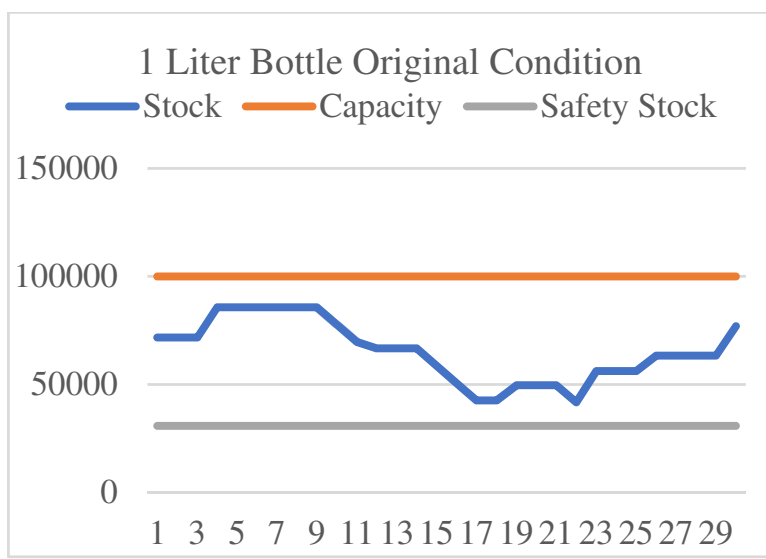

Fig. 1. 1L Bottle graph initial condition

Based on the MRP calculation for the $1 \mathrm{~L}$ insecticide packaging bottle on initial condition in Fig. 1, the Net value requirement for each period is 0 because the previous quantity of schedule receipt can cover each period's gross requirement. Project On Hand has a high demand in the $10^{\text {th }}-$ $24^{\text {th }}$ period. On period $22^{\text {nd, }}$ Hand's project has an unstable condition and close to the lowest quantity with a total Project on Hand 41,669 units. The vertical axis shows the units, and the horizontal axis shows the period.

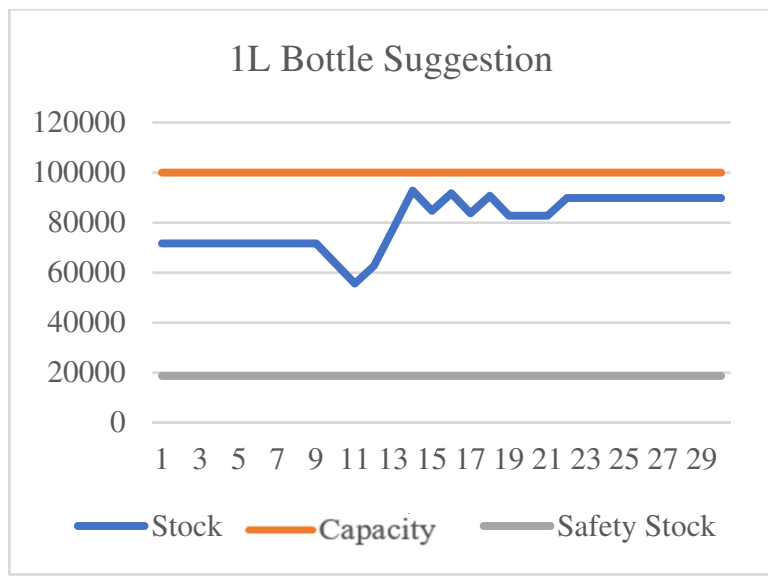

Fig. 2. 1L Bottle graph proposed condition

It considers various factors such as storage capacity, safety stock, demand, and truck capacity, and the proposed order scheme is used to improve or guide when making an order. Therefore, orders with considering inventory and demand will be more stable, shown in Fig. 2. Notice unstable demand in the company, then implement a threeperiod reorder point for $1 \mathrm{~L}$ insecticide packaging bottle in a month. The reorder point for the 1 st period is 34,680 units, where the company will make an order if inventory is less than the reorder point. The reorder point $2^{\text {nd }}$ period is 66,824 units, and the reorder point $3^{\text {rd }}$ period is 26,668 units.

The company only needs to order the bottle five times, compared to the previous condition needs seven times, where the company needs to make order seven times ( 2 times save). The other benefit is order and inventory are more stable close to demand. The following is a comparison chart using initial and proposed data in Fig. 3.

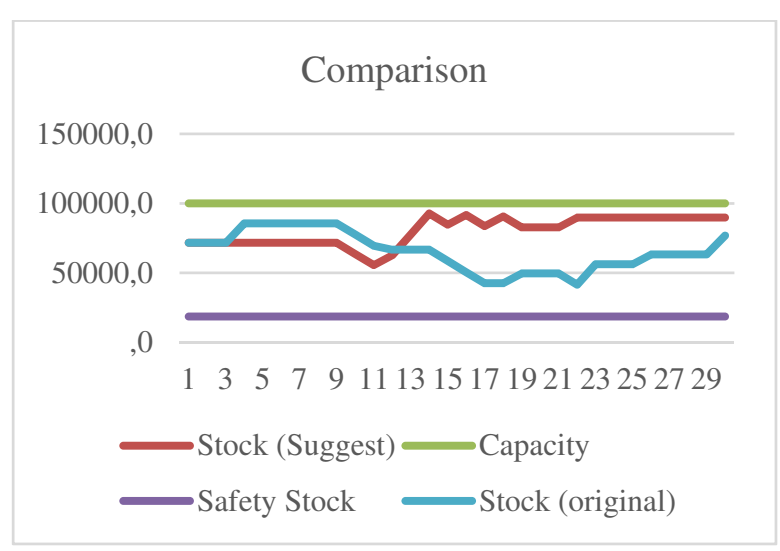

Fig. 3. Comparison of initial vs proposed

Research with the MRP method has been widely used in various industries, for example apparel [6], paper [11], cement [12], automobile [13], garment [15], construction [16], motorcycle chains [17], talc powder [18], screen printing ink [19], briquette [20], sewing thread [21], pharmaceuticals [22], alloy cast [23], and coconut sugar [24]. The majority of existing research discusses the raw materials for making finished products. There are not many studies that discuss packaging. Packaging supplies are important because they complement the products being marketed, and the amount must meet the amount of products. Excess packaging inventory increases storage costs, and a shortage of packaging inventory hinders the packaging process. In addition, proper ordering frequency can reduce the cost incurred by the company.

\section{CONCLUSION}

The proposed order scheme for ordering $1 \mathrm{~L}$ insecticide packaging bottle improve the company on reducing the frequency for ordering bottles from 7 times to 5 times and inventory is more stable and close to demand quantity. In future research, MRP calculations can be carried out by comparing various methods and conducting a 
sensitivity analysis of the proposed results. PT. Agricon has not implemented an ordering system for raw material of $1 \mathrm{~L}$ pesticide bottles using safety stock. This impact on inventory accumulation occurs in the warehouse (waste of inventory). Project On Hand on $10^{\text {th }}-24^{\text {th }}$ period for $1 \mathrm{~L}$ insecticide packaging bottle is not stable because inventory vs demand not precisely catches. Implemented safety stock and reorder points will improve the inventory control and make it more durable.

\section{REFERENCES}

[1] R. Guillaume, C. Thierry, and P. Zieliński, "Robust material requirement planning with cumulative demand under uncertainty," Int. J. Prod. Res., vol. 55, no. 22, pp. 6824-6845, Nov. 2017, doi: 10.1080/00207543.2017.1353157.

[2] A. Afriansyah and A. S. Mohruni, "Production Planning and Control System with Just in Time and Lean Production: A Review," J. Mech. Sci. Eng., vol. 6, no. 2, pp. 19-27, 2019. Available: https://ejournal.unsri.ac.id/index.php/jmse /article/view/10285.

[3] R. Hencha and D. S. Verma, "Study of Material Requirement Planning Processes and Its Analysis and Implementation (A Case Study of Automobile Industry)," Int . J. Sci. Technol. Res., vol. 8, no. 8, pp. 648 653, 2019, Available: https://www.ijstr.org/finalprint/aug2019/Study-Of-MaterialRequirement-Planning-Processes-ItsAnalysis-And-Implementation-a-CaseStudy-Of-Automobile-Industry.pdf.

[4] D. Gradišar and M. Glavan, "Material Requirements Planning Using VariableSized Bin-Packing Problem Formulation with Due Date and Grouping Constraints," Processes, vol. 8, no. 10, pp. 1-6, Oct. 2020, doi: 10.3390/pr8101246.

[5] M. Díaz-Madroñero, J. Mula, and M. Jiménez, "Material Requirement Planning under Fuzzy Lead Times," IFACPapersOnLine, vol. 48, no. 3, pp. 242-247, 2015, doi: 10.1016/j.ifacol.2015.06.088.

[6] A. Iasya and Y. Handayati, "Material requirement planning analysis in micro, small and medium enterprise case study: grooveline-an apparel outsourcing company final project," J. Bus. Manag., vol. 4, pp. 317-329, 2015. Available: https://journal.sbm.itb.ac.id/index.php/jb $\mathrm{m} /$ article/view/1628.

[7] R. J. Najy, "MRP (Material Requirement Planning) Applications in Industry-A REVIEW," IJRDO - J. Bus. Manag., vol. 6, no. 1, pp. 1-13, 2020. Available: http://www.ijrdo.org/index.php/bm/article /view/3442.

[8] C. Furqon, M. A. Sultan, and R. J. Pramudita, "Analysis of Material Requirement Planning (MRP) Implementation on The Company," in Proceedings of the 2nd International Conference on Economic Education and Entrepreneurship, 2017, pp. 140-145, doi: $10.5220 / 0006882001400145$.

[9] D. Więcek, D. Więcek, and L. Dulina, "Materials Requirement Planning with the Use of Activity Based Costing," Manag. Syst. Prod. Eng., vol. 28, no. 1, pp. 3-8, Mar. 2020, doi: 10.2478/mspe-2020-0001.

[10] B. A. Mtengwa and J. A. Malleo, "Stakeholder's Perception on Quality of Mergers and Acquisitions in Tanzania," Int. J. Acad. Res. Bus. Soc. Sci., vol. 8, no. 10, pp. 1216-1227, Nov. 2018, doi: 10.6007/IJARBSS/v8-i10/4832.

[11] E. Rimawan, D. S. Saroso, and P. E. Rohmah, "Analysis of Inventory Control with Material Requirement Planning (MRP) Method on IT180-55gsm F4 Paper Product at PT. IKPP, TBK," Int. J. Innov. Sci. Res. Technol., vol. 2, no. 2018, pp. 569-581, 3AD. Available: https://ijisrt.com/wpcontent/uploads/2018/02/Analysis-ofInventory-Control-with-MaterialRequirement-Planning-MRP-Method.pdf.

[12] W. A. Y. Bunga and D. I. Rinawati, "Perencanaan Persediaan Bahan Baku Semen Dengan Menggunakan Metode Material Requirement Planning (Mrp) Pada PT Indocement Tunggal Prakarsa Tbk. Plant Cirebon," Ind. Eng. Online J., vol. 7, no. 4, pp. 1-8, 2019. Available: https://ejournal3.undip.ac.id/index.php/ieo $\mathrm{j} /$ article/view/22991.

[13] D. Gharakhani, "Optimization of material requirement planning by goal programming model," Asian J. Manag. Res., vol. 2, no. 1, pp. 297-317, 2011. Available: 
http://ipublishing.co.in/ajmrvol1no1//volt wo/EIJMRS2027.pdf.

[14] T. T. Amachree, E. O. P. Apkan, E. C. Ubani, and K. A. Okorocha, "Validation Of Developed Materials Requirement Planning (MRP) Integrated Flow System Model Of Ims For Piemf," Int. J. Sci. Technol. Res., vol. 6, no. 8, pp. 355-361, 2017.

Available:

https://www.ijstr.org/final-

print/aug2017/Validation-Of-Developed-

Materials-Requirement-Planning-mrp-

Integrated-Flow-System-Model-Of-Ims-

For-Piemf.pdf.

[15] N. Hasanati, E. Permatasari, N. Nurhasanah, and S. Hidayat, "Implementation of Material Requirement Planning (MRP) on Raw Material Order Planning System for Garment Industry," IOP Conf. Ser. Mater. Sci. Eng., vol. 528, no. 1, pp. 1-8, Jun. 2019, doi: 10.1088/1757-899X/528/1/012064.

[16] A. Imetieg and M. Lutovac, "Project scheduling method with time using MRP system: A case study: Construction project in Libya," Eur. J. Appl. Econ., vol. 12, no. 1, pp. 58-66, 2015, doi: 10.5937/ejae127815.

[17] S. Kurniawan and S. S. Raphaeli, "Optimizing Production Process through Production Planning and Inventory Management in Motorcycle Chains Manufacturer," ComTech Comput. Math. Eng. Appl., vol. 9, no. 2, pp. 43-53, Dec. 2018, doi: 10.21512/comtech.v9i2.4723.

[18] F. Lefta, L. Gozali, and I. A. Marie, "Aggregate and Disaggregate Production Planning, Material Requirement, and Capacity Requirement in PT. XYZ," IOP Conf. Ser. Mater. Sci. Eng., vol. 852, no. 1, pp. 1-6, Jul. 2020, doi: 10.1088/1757899X/852/1/012123.

[19] P. Theresia and L. L. Salomon, "Usulan Penerapan Material Requirement Planning (MRP) Untuk Pengendalian Persediaan Bahan Baku Produk ANT INK (Studi Kasus: CV. Sinar Mutiara)," J. Kaji. Teknol., vol. 11, no. 1, pp. 43-54, 2015. Available:

http://journal.untar.ac.id/index.php/teknol ogi/article/view/618.
[20] Y. E. Torunoglu, H. K. Akin, and N. Guler, "Material Requirement Planning in a Briquette Factory," Int. Adv. Res. Eng. J., vol. 1, no. 1, pp. 21-25, 2017. Available: https://dergipark.org.tr/en/pub/iarej/issue/ 33993/378300.

[21] D. Abrianto and D. Riandadari, "Perencanaan Persediaan Bahan Baku Produksi dengan Metode Material Requirement Planning (MRP) Pada PT. Sejati Jaya," J. Pendidik. Tek. Mesin, vol. 06, no. 01, pp. 77-83, 2016. Available: https://jurnalmahasiswa.unesa.ac.id/index. php/jurnal-pendidikan-teknik-

mesin/article/view/21045

[22] A. Chandradevi and N. B. Puspitasari, "Penerapan Material Requirement Planning (MRP) dengan Mempertimbangkan Lot Sizing dalam Pengendalian Bahan Baku pada PT. Phapros, Tbk.," PERFORMA Media Ilm. Tek. Ind., vol. 15, no. 1, pp. 77-86, 2016, doi: 10.20961/performa.15.1.13760.

[23] T. Y. T. Kusuma, "Analisis Material Requirement Planning (MRP) di C-Maxi Alloycast," Integr. Lab J. Available: http://ejournal.uin-

suka.ac.id/pusat/integratedlab/article/view /1556 vol. 5, no. 2, pp. 81-94, 2017.

[24] K. A. Martha and P. Y. Setiawan, "Analisis Material Requirement Planning Produk Coconut Sugar Pada Kul-Kul Farm," EJurnal Manaj. Univ. Udayana, vol. 7, no. 12, p. 6532, 2018, doi: 10.24843/ejmunud.2018.v07.i12.p06.

[25] A. P. Velasco Acosta, C. Mascle, and P. Baptiste, "Applicability of DemandDriven MRP in a complex manufacturing environment," Int. J. Prod. Res., vol. 58, no. 14 , pp. 4233-4245, 2020, doi: 10.1080/00207543.2019.1650978.

[26] J. I. Romero-Gelvez, E. A. Delgado-Sierra, J. A. Herrera-Cuartas, and O. GarciaBedoya, "Demand Forecasting and Material Requirement Planning Optimization Using Open Source Tools," CEUR Workshop Proc., vol. 2486, no. November, pp. 94-107, 2019. Available: http://ceur-ws.org/Vol-

2486/icaiw_wdea_5.pdf 